\title{
Effective Language Teaching Through Active Learning
}

\author{
Karthika Devi. S and Jeyavani. S \\ Department of English, Builders Engineering College, Kangayam, Tamilnadu, India
}

\section{ABSTRACT}

Learning is boundless. Human civilization started its development through learning. Man used language as a mode of communication and it is a part of learning. Language is essential for the effective functioning of a society. It reflects the personality of the individual through expansion of knowledge. Mother tongue plays an essential part in meaningful learning. New ideas and innovations are possible through meaningful learning. Rote learning decreases the interest of learners. The full involvement and further thinking through meaningful learning enable everyone to active learning. Learners have to adapt for the environment and to integrate the past experiences with the present situation to gain better knowledge. Teaching language through different techniques of active learning like one minute paper, role play, discussion, think pair and share would further empower a learner. Cooperative learning and collaborative learning are different methods for language teaching. This paper suggests that using multiple activities will efficiently facilitate language teaching.

\section{KEY WORDS: LEARNING, ACTIVE LEARNING, LANGUAGE, EFFECTIVE, INTEGRATE}

\section{INTRODUCTION}

English Language teaching has become a challenging task in higher education. In a professional college, students are admitted from different medium of instruction. In some schools the mother tongue is medium of instruction so in the higher education students suffer a lot to learn through English. Though English is learnt as a second language, the learners are not trained to use language efficiently. Due to advancements and development in society different methodologies of teaching can be used to promote active learning. Meaningful learning through diverse activities will promote effective language teaching in higher education.

Learning is a form of continuous activity,it is acquired from childhood. The real change in behaviour is learning. Knowledge and experience gained through every situation should be refined for a better change. Motivation and involvement in every activity is learning. Society is responsible for everyone's learning. Interest in every individual will promote learning. New technologies have

Biosc Biotech Res Comm P-ISSN: 0974-6455 E-ISSN: 2321-4007

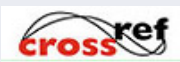

Identifiers and Pagination

Year: 2021 Vol: 14 No (8) Special Issue

Pages: 64-65

This is an open access article under Creative

Commons License Attribn 4.0 Intl (CC-BY). DOI: http://dx.doi.org/10.21786/bbrc/14.8.15 made a great impact in teaching a language. Language promotes understanding and to know about ideas of the society.

The interactions and experiences gained in society through language acquisition will foster improvement in a person. In higher education the learners will be multilingual and attention should be paid for language teaching. Guidance and self interest is essential for learning any language. To organize our perceptions, learning in a meaningful way will help in acquiring a language.Everyone's learning will be fruitful if it is a meaningful learning. The abilities and skills of every individual differ. Learning will lasts longer in the minds of a learner if it is meaningful. Many students in school education learn through rote learning.Due to lack of involvement of learner, rote learning takes place. It will decrease interest in learning and second language learning will not be possible. The full participation is essential in any language learning and active learning methods can be used to improve language teaching.

Active Learning: Active learning is a process in which students involve actively or experientially. Bonwell \& Eison, (1991) mentions that "students participate in active learning when they are doing something besides passively listening". So the learners will involve in meaningful learning activity and thinking about what they do. Improvement in any language will occur if a learner learns new vocabulary and continuous speaking activity.
Article Information

Received: $19^{\text {th }} \mathrm{Apr} 2021$ ccepted after revision: $05^{\text {th }}$ May 2021 
Language teaching through active participation of students will evolve a great involvement in learning.

\section{Techniques of Active Learning:}

1. Role Play: In a language teaching classroom students can be asked to participate in role play. They can be in pairs and one situation can be given to them to enact. Time should be given as ten minutes to each pair for preparation. This will actively promote student's vocabulary and communication skills. Thinking process takes down and social skills will be developed. Here learning takes place actively and this helps the teacher to teach language effectively.

2. Think - Pair - Share: In higher classes students can be given different topics to speak in a language classroom. The teacher can regularly follow this activity. Teacher can give topics at the beginning of a class and some time can be provided to students to think and share their views with their classmates. This will enhance their communication and the language fluency can be developed.Learners will feel free to speak among his friends. The views about language learning will be made easy for students in a multilingual classroom.

3. Peer Review: The Language teacher may ask the learners in the classroom to give comments about the topic that was taught on that day at the end of the class. Everyone can be given chance to express their views. This activity will promote interest for the learners and also this encourages active participation in oral communication.

4. Discussion: Discussion is an active learning experience for the students than the lecture. Students are divided into group of six or seven members and an interesting topic can be suggested by the Teacher. This will stimulate interest and thinking in every learner. Language teachers can often emphasis this activity. Learners will understand and think about a particular concept, it results in permanent learning of a language.

5. Cooperative Learning: This learning process is student centered and it provides opportunity for students to learn in groups. Language teaching through this Cooperative learning will be a suitable learning environment for students. A class can be divided into five to eight members in a team. Team should have students of higher learning and lower learning ability. After the completion of each topic students can be allowed to discuss the same topic in their team and can be encouraged to do exercises in the book. While doing exercises, group members will get their doubts clarified by the other member of the group. Atlast the teacher can observe their learning through evaluation. This will help to attain proficiency in learning.

6. Collaborative Learning: Collaborative learning encourages students to work in groups. If the group is of six members then all six will be involved to work for this method. One has to gather information, other has to process the information, next person has to organize the information, another student has to reorganize and other one will involve in compiling the work. This has a mutual dependence and sharing of learning.

\section{CONCLUSION}

This article recommends that language teaching will be effective if it is learned with involvement and meaningful learning of the learner. Active learning techniques will also enhance students in multilingual classroom. These methods can help students to build self confidence and self-esteem. Teaching - learning environment can be well developed in higher education through active learning. Effective language teaching paves the way for students to learn new things. In higher education teachers can follow new techniques in teaching to empower the students to face their future.

\section{REFERENCES}

Prof. K. Nagarajan \& Dr.S.Natarajan. (2018) Language Across The Curriculum: Text-book written as per the New Syllabus introduced in 2016 by the Tamil Nadu Teacher Education University, pp-1-20.

Prof. K. Nagarajan \&t Dr.S.Natarajan. (2018) Learning and teaching: Text-book written as per the New Syllabus introduced in 2016 by the Tamil Nadu Teacher Education University, pp-1-27.

https://en.wikipedia.org/wiki/Collaborative_learning (23.3.2021)

https://learninginnovation.duke.edu/resources/artand-science-of-teaching/active-learning-techniquesclassroom/ (3.3.2021)

https://teaching.berkeley.edu/active-learning-strategies (11.3.2021)

https://www.earlystartgroup.com/nursery/importanceof-role-playing/ (3.3.2021) 